\author{
Irina Zimonyi-Kalinyina \\ (iD) https://orcid.org/0000-0003-2406-6381 \\ Budapest, Hungary \\ e-mail: irina_zimonyi@hotmail.com
}

\title{
Thematic category of meal, cuisine, and hospitality in the Hungarian proverbial lore
}

\begin{abstract}
This study is aimed on the thematic selection of the Hungarian proverbs dealing with gastronomy and hospitality both in direct and figurative way. As a source for this compilation we used recent and earlier editions of the proverbs' dictionaries. We searched for proverbs using keywords, and not only. A substantial number of proverbs was identified as belonging to this thematic group. Through the comparative and descriptive approach, we divided all the selected proverbial material into subgroups. A special semantic filter was applied to distinguish the proverbs containing so-called Hungarikum realia. The selection of Hungarian proverbs for this thematic groups was also used in order to contribute to the theory of the common Central-European linguistic area.
\end{abstract}

Keywords: Cuisine, gastronomy, hospitality, Hungarian, Hungarikum, proverbs

\section{Introduction}

In this study we introduce a selection of Hungarian proverbs regarding alimentation, gastronomy, and hospitality. The significant number (over 80) of proverbs detected proves this matter vital and deserving of closer examination. The basic resource of our study was the Big Dictionary of Hungarian proverbs which contains 2000 items.

In course of this research:

a. an overview of this thematic cluster of proverbs in the known classification systems has been made;

b. using the method of continuous sampling we filtered out proverbs belonging to the thematic category; 
c. having examined the semantics of the selected proverbs we divided them into four subgroups;

d. a special semantic selection of so-called Hungarikum proverbs has been made;

e. Czech, Slovak and Slovenian parallels to the given thematic group of Hungarian proverbs were identified in order to consider the theory of the common Central-European linguistic area on the paremiological level.

a. Among the components of the proverbs there are many terms meaning food and alimentation. The most known systematizations usually do not position these proverbs in the same category but use other criteria for their categorization. In the Matti Kuusi International Type System and the Database of Proverbs, subjects like hunger, food, drinking are mainly represented in the category D as DYNAMICS OF NEEDS: D3a distress, need and hunger activate; lead to ideas, innovations or crimes; D3b love and hunger mobilize; beauty and source of food attract; D3e hunger or shortage lowers one's standards, makes one passive; D3f hunger depresses, sleeplessness lowers capacity of work; the one who is full \& well-rested is carefree; D3h insatiable greed leads to disappointment; D3i moderation is best $>$ overeating is bad for your health; D3j regulating one's food consumption with the future in mind; FOOD, EATING: D4a the importance of food for human beings and animals; D4b appetite and hunger; D4c foodstuffs and dishes; D4d eating habits and norms; SPIRITS AND BEING DRUNK / DEPENDENCES, DRINKING HABITS: D5a appreciation of alcohol, drinking habits or norms; D5b craving for drink or cigarettes; D5c drunkenness : madness; D5d intoxication and state of mind; D5e financial and social costs of drinking. Hospitality is included in category H SOCIAL INTERACTION: H5 ME/US /OWN ADVANTAGE: OTHERS /HOSPITALITY TOWARDS GUESTS: H5e hospitality and its limits; H5f uninvited guests and unsolicited aid, etc. But inserting in browser such keywords as "milk" or "wine" will result other categories, too.

In the Thematic Index of Russian Proverbs in the Russian-Slavonic Dictionary of Proverbs by M. Kotova (2000) we detect the following categories: II. PERSON (HUMAN) 3) Drunk-sober; V. PROPERTY. OWNER. GUEST. WEALTH 2) Host-guest 3) Food, treat; VIII. THE RELATIONSHIP BETWEEN PEOPLE 6) Fed-hungry. In this classification we can see again a spread of our target group of proverbs between different categories.

b. In course of the selection we took into consideration not the single components, but the semantical meaning of the given proverb. The well-known and widespread One rotten apple will spoil the whole barrel or Big fish eat small fish have nothing to do with the consumption of fruit or fish. There are also numerous Hungarian examples like Akinek vaj van a fején, ne menjen a napra /lit. If you have butter on your head, don't go in the sun/; Kutyából nem lesz szalonna /lit. You can’t make lard out of a dog/; Kecskére nem bizzák a káposztát /lit. Don't leave the cabbage to the goat/. We don't consider such proverbs as belonging to the thematic group and examine only those which express the phenomena of alimentation and hospitality, holding either direct or indirect meaning.

c. The thematic category in this study is divided in four semantic subgroups: direct meaning (wisdom, experience, instruction), dual semantics (strong direct meaning + figurative meaning), comparison, figurative meaning expressed by thematic imagery. The statistical breakdown of the subgroups is as follows: 


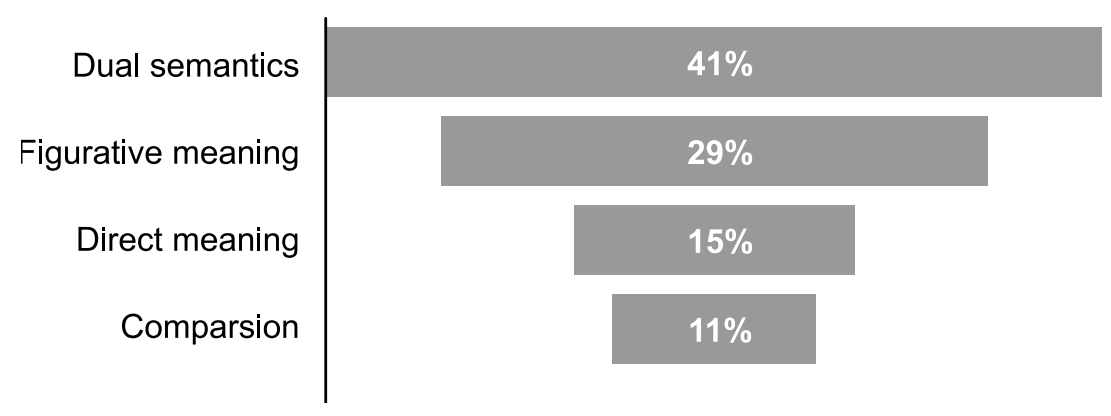

We can see that in most of the proverbs a kind of figurative meaning is applied, and the thematic imagery is used as a communication tool of a broader message.

Below we will introduce the whole compilation starting from direct meeting and gradually proceeding to more abstract semantics.

\section{Direct meaning (wisdom, experience, instruction)}

In this subgroup we included the proverbs conveying direct advises, long-time observations, sapience of ancestors. According to our statistics they represent $15 \%$ of the total quantity within the thematic group.

\begin{tabular}{|l|l|}
\hline A retek reggel méreg, délben étek, este orvosság & $\begin{array}{l}\text { lit. Radish in the morning is a poison, at noon - } \\
\text { a food, in the evening - a medicament }\end{array}$ \\
\hline $\begin{array}{l}\text { Ahol ketten jóllaknak, a harmadik sem marad } \\
\text { éhes }\end{array}$ & $\begin{array}{l}\text { lit. Where two persons saturate, the third one } \\
\text { will not stay hungry, too }\end{array}$ \\
\hline Átkozott a hal a harmadik vízben & lit. Cursed is the fish in the third water \\
\hline Bor be, ész ki & lit. Wine in, sense out \\
\hline Bor nélkül szegény a vendégség & lit. Hospitality is poor without wine \\
\hline $\begin{array}{l}\text { Jobb, ami a tálban marad, mint ami a hasba } \\
\text { szalad }\end{array}$ & $\begin{array}{l}\text { lit. Better is what remains on platter, than what } \\
\text { falls into belly }\end{array}$ \\
\hline Jó a sör, de (mégis) bor (annak) az anyja & lit. Beer is good, but still the wine is its mother \\
\hline $\begin{array}{l}\text { Jó bor, (pénz,) szép asszony embert kíván } \\
\text { őrzésre (régi) }\end{array}$ & $\begin{array}{l}\text { lit. To guard a good wine, (money), a beautiful } \\
\text { woman a real man is needed (old) }\end{array}$ \\
\hline Megmutatja a bor, kiben mi lakik & lit. The wine will show, what resides in whom \\
\hline Nincs a bornak titka & lit. Wine has no secrets \\
\hline Sok étel betegség & lit. Much food means illness \\
\hline Üres has nem jó (rossz) tanácsadó & lit. An empty belly is not good (bad) adviser \\
\hline Üres hasnak nem elég a szép szó & \begin{tabular}{l} 
lit. Fair words are not enough to an empty belly \\
\hline
\end{tabular}
\end{tabular}

Three of the proverbs deal with hunger, another two alerts for moderation in food consumption, one gives conduct for consuming radish, and seven are dedicated to wine, 
its qualities and its influence on people. To better understand the proverb Atkozott a hal a harmadik vizben /lit. Cursed is the fish in the third water/ we must answer the question: which is the third water for the fish? The first one is the fish is swimming in, in the second water it is cooked, and the third should be the water drunk while eating fish - but that is cursed! So, the proverb strongly advises to accompany fish dishes with wine.

\section{Semantic duality: strong direct meaning + figurative meaning}

Proverbs included in this subgroup at first sight describe the thematic realities of this groups, but simultaneously include a universal teaching.

\begin{tabular}{|c|c|}
\hline A jó bornak is kell (a) cégér & lit. Even a good wine needs signboard/bush \\
\hline A jó bornak nem kell cégér & lit. Good wine needs no signboard/bush \\
\hline A keserü babot is édessé teszi az éhség & lit. The hunger makes bitter bean sweet \\
\hline A jó gyomor mindent megemészt & lit. A good stomach digests everything \\
\hline A legjobb bornak is van söprüje (régi) & Even the best wine has sediment (old) \\
\hline A kolbász is elfogy, akármilyen hosszú & lit. The sausage will run out, being of any length \\
\hline Ahol a bor az úr, ott az ész koldulni jár & $\begin{array}{l}\text { lit. Where the wine is the lord, the mind is } \\
\text { a beggar }\end{array}$ \\
\hline Aki kicsit föz, hamar megeszi & lit. He who cooks few, eats it quickly \\
\hline Aki leszedte a tejfelt, igya meg a savóját is & $\begin{array}{l}\text { lit. Who removed the cream, must drink the } \\
\text { whey, too }\end{array}$ \\
\hline $\begin{array}{l}\text { Akinek a kása megégeti a száját, az aludttejet } \\
\text { is megfújja }\end{array}$ & $\begin{array}{l}\text { lit. He whose mouth was once burned by hot } \\
\text { mush, blows even at sour milk }\end{array}$ \\
\hline Annak, aki éhes, a kenyérhéj is édes & lit. The bread crust is sweet for who is hungry \\
\hline Az éhes ember nem válogat & lit. The hungry person is not choosy \\
\hline Az új fazék megtartja első szagát & $\begin{array}{l}\text { lit. A new pot retains its first scent/ (The cask } \\
\text { savours of the first fill) }\end{array}$ \\
\hline Azzal fözünk, amink van & lit. We are cooking [using] what we have \\
\hline Bolond, aki sört iszik, mikor bort ihat & $\begin{array}{l}\text { lit. Stupid is who drinks beer when he can } \\
\text { drink wine }\end{array}$ \\
\hline $\begin{array}{l}\text { Bor, pecsenye [bor és kenyér] nélkül a szerelem } \\
\text { meghűl }\end{array}$ & $\begin{array}{l}\text { lit. Love cools down without wine, roast (wine } \\
\text { and bread) }\end{array}$ \\
\hline Bor s kenyér nélkül fázik a bujaság (régi) & $\begin{array}{l}\text { lit. Passion is freezing without wine and bread } \\
\text { (old) }\end{array}$ \\
\hline $\begin{array}{l}\text { Bort sajt után (régi) < sajt után nem szabad bort } \\
\text { inni, mert ilyenkor a rossz bor is ízlik> }\end{array}$ & $\begin{array}{l}\text { lit. Wine after cheese (old) 〈after cheese even } \\
\text { a bad wine seems tasty〉 }\end{array}$ \\
\hline Csak legjobb a tejnek a föle & lit. The cream is the best on milk \\
\hline Eszi, nem eszi, nem kap mást & $\begin{array}{l}\text { lit. He may eat it or not (eat), he won't get } \\
\text { anything else }\end{array}$ \\
\hline
\end{tabular}




\begin{tabular}{|c|c|}
\hline Evés közben jön meg az étvágy & lit. Appetite comes while eating \\
\hline Ha leszedted a fölét, edd meg az alját is & $\begin{array}{l}\text { lit. If you took off the cream, eat the bottom } \\
\text { part, too }\end{array}$ \\
\hline Ha kalács nincs, jó a kenyér is & lit. If there is no brioche, bread is okay \\
\hline $\begin{array}{l}\text { Késő a kolbászt akkor kímélni, amikor már } \\
\text { elfogyott }\end{array}$ & $\begin{array}{l}\text { lit. It is late to spare the sausage when it is } \\
\text { already run out }\end{array}$ \\
\hline $\begin{array}{l}\text { Kész ebéd, kész vacsora nem vereti meg az } \\
\text { asszonyt }\end{array}$ & $\begin{array}{l}\text { lit. Ready lunch, ready dinner doesn't make the } \\
\text { wife beaten }\end{array}$ \\
\hline Ki mit fözött, egye meg & $\begin{array}{l}\text { lit. What you have cooked, you should eat as } \\
\text { well }\end{array}$ \\
\hline Kicsi a bors, de erős & lit. Pepper is small but strong \\
\hline Könnyü tele hassal a böjtöt dicsérni & lit. It is easy to praise the fast when belly is full \\
\hline $\begin{array}{l}\text { Lencse, borsó, kása diák táplálása (mind Isten } \\
\text { áldása) }\end{array}$ & $\begin{array}{l}\text { lit. Lentils, green peas, mush are the student's } \\
\text { meal (are all God's blessing) }\end{array}$ \\
\hline Más szájával nem lehet jóllakni & $\begin{array}{l}\text { lit. It is impossible to satisfy hunger by other's } \\
\text { mouth }\end{array}$ \\
\hline Meglátszik, melyik tejből lesz túró & lit. It is obvious, which milk will result curd \\
\hline Minden ember az ő maga fazeka mellé szít & lit. Every man kindles the fire below his own pot \\
\hline $\begin{array}{l}\text { Nincs olyan szakács, hogy mindenkinek szája } \\
\text { ízére főzzön }\end{array}$ & lit. No cook is able to cook for everybody's taste \\
\hline Olcsó húsnak híg a leve & lit. Cheap meat yields dilute soup \\
\hline Szegény ember vízzel főz & lit. Poor man cooks with water \\
\hline
\end{tabular}

This subgroup is opened by paremiological antonyms, which differ by positive/ negative form of verb: A jó bornak is kell cégér/lit. Even a good wine needs signboard/A jó bornak nem kell cégér /lit. Good wine needs no signboard/. The two well-known proverbs are more used as a qualification of personal performance rather than for quality wine promotion.

The stylistically coloured (rude) popular proverb Eszi, nem eszi, nem kap mást /lit. He may eat it or not (eat), he won't get anything else/ not only clearly, but in a sharp tone restricts the offer to one single possibility.

Kicsi a bors, de erös /lit. Pepper is small but strong/ - this proverb operates with the dual meaning of the word "erös" in the Hungarian language: "strong" and "hot, spicy". This provides the semantic duality of the proverb: the physical dimension does not always coincide with capabilities and abilities.

Olcsó húsnak híg a leve /lit. Cheap meat yields dilute soup/; Szegény ember vízzel $f_{o z}^{\prime \prime}$ /lit. Poor man cooks with water/ - these two proverbs point on the limited available resources, which result poor outcome ("dilute soup"), but sometimes we are forced to satisfy ourselves with what we have at our disposal ("cook with water" - instead of broth). 


\section{Comparison}

The proverbs in this subgroup use the easily understandable imagery of cooking and nutrition as argumentation or explanation.

\begin{tabular}{|l|l|}
\hline Akinek nem forró, ne fújja a kását & lit. Who does not feel hot, don’t blow the mush \\
\hline Az éhség nagy úr & lit. Hunger is a big lord \\
\hline Az élet nem habos torta & lit. Life is not a cake with whipped cream \\
\hline Harmadnapra mind a hal, mind a vendég büdös & $\begin{array}{l}\text { lit. On the third day both the fish and the guest } \\
\text { are stinky }\end{array}$ \\
\hline Kása nem étel, tót nem ember & $\begin{array}{l}\text { lit. Mush (porridge) is not food, Slovak is not } \\
\text { a human }\end{array}$ \\
\hline Legjobb füszer (szakács) az éhség & lit. Hunger is the best spice (cook) \\
\hline Régi bor jó bor, öreg ész finom ész & lit. Old wine - good wine, old mind - fine mind \\
\hline Több az emberség a káposztás húsnál & $\begin{array}{l}\text { lit. The humanity is bigger than the meat with } \\
\text { cabbage }\end{array}$ \\
\hline Többen halnak borban, mint a tengerben (régi) & $\begin{array}{l}\text { lit. More (people) die in wine, than in the sea } \\
\text { (old) }\end{array}$ \\
\hline
\end{tabular}

In the proverbs of this subgroup hunger is compared to a big governor (Az éhség nagy úr /lit. Hunger is a big lord/), to the best spice or an able cook (Legjobb füszer (szakács) az éhség /lit. Hunger is the best spice (cook)/).

The modern and a very popular proverb Az élet nem habos torta /lit. Life is not a cake with whipped cream/ has an interesting origin. It derives from the Hungarian satire film A tanú (The Witness) made in 1969 (Director Péter Bacsó). The film was created in a tense political climate; although it was financed and allowed to be made by the communist authorities, it was subsequently banned from release, because it introduced in satiric form the realities of the communist regime. The quoted saying - which later became a proverb - comes from one of the main characters of the film, a big state security boss.

Harmadnapra mind a hal, mind a vendég büdös /lit. On the third day both the fish and the guest are stinky/. This proverb is a well-known one. In the dictionary European Proverbs in 55 languages (Paczolay, 2002) this proverb occupies the $58^{\text {th }}$ place within 106 most popular proverbs in 55 languages. (Fish and guests smell in three days.)

\section{Figurative meaning expressed by thematic imagery}

The definition "most proverbs are short statements of general validity in a particular field, often in poetic form" (Paczolay, 2002) is especially valid for the proverbs holding a kind of hidden message. The proverbs selected for this subgroup use the thematic imagery as an expressive toolkit and show the high fly of creativity. The message and teaching of these proverbs fall far from their literary meaning. 


\begin{tabular}{|c|c|}
\hline A tiltott alma jobb ízü & lit. Forbidden apple tastes better \\
\hline Addig a barátság, míg zsíros a konyha & $\begin{array}{l}\text { lit. Friendship lasts until the cuisine is fatty } \\
\text { (rich) }\end{array}$ \\
\hline $\begin{array}{l}\text { Aki a keserüt nem kóstolta, nem tudja, mi az } \\
\text { édes }\end{array}$ & $\begin{array}{l}\text { lit. Who did not taste the bitter doesn't know } \\
\text { what is sweet }\end{array}$ \\
\hline Aki a kondérnál ül, azé a kövérje & lit. He who sits next to cauldron, gets greasy \\
\hline A puding próbája az evés & lit. The proof of the pudding is in the eating \\
\hline Az ember a fogával ás magának vermet & lit. Man digs pit for himself with his teeth \\
\hline Borban az igazság & lit. In wine is truth / In vino veritas \\
\hline Elég egy sütésből egy lepény & lit. One flatbread is enough from one baking \\
\hline Fejétől büzlik a hal & lit. The fish rots from the head down \\
\hline Felmelegítve csak a töltöttkáposzta jó & $\begin{array}{l}\text { lit. Only the stuffed cabbage is good if warmed } \\
\text { up }\end{array}$ \\
\hline $\begin{array}{l}\text { Jobb a száraz kenyér békességgel, mint a hizlalt } \\
\text { borjú perlekedéssel }\end{array}$ & $\begin{array}{l}\text { lit. Dry bread in peace is better than fattened } \\
\text { veal in conflict }\end{array}$ \\
\hline Jóllakott méhnek nem kell a virág & lit. A saturated bee does not want flower \\
\hline Keserü a más kenyere & lit. Others' bread is bitter \\
\hline Későn jött vendégnek csont a vacsorája & lit. Late guest's dinner is a bone \\
\hline Lesz még szőlő, lesz még lágy kenyér & lit. There will be grapes, will be soft bread \\
\hline Nem csak kenyérrel él az ember & lit. Man shall not live by bread alone \\
\hline Nem erőszak a disznótor & $\begin{array}{l}\text { lit. Nobody is forced to attend the dinner given } \\
\text { after Pig slaughtering }\end{array}$ \\
\hline $\begin{array}{l}\text { Nem eszik olyan forrón a kását (mint ahogy } \\
\text { fózik) }\end{array}$ & lit. Mush/Soup is not eaten as hot as it is cooked. \\
\hline Nem azé a kalács, aki süti, hanem aki megeszi & $\begin{array}{l}\text { lit. Brioche is not owned by who bakes it, but } \\
\text { by who eats it }\end{array}$ \\
\hline Nem mind szakács, aki kalánt a kezébe veszi & $\begin{array}{l}\text { lit. Not everyone who takes a spoon in hand } \\
\text { is a cook }\end{array}$ \\
\hline $\begin{array}{l}\text { Nincs az az oldalszalonna, amelyik meg ne } \\
\text { szünne }\end{array}$ & $\begin{array}{l}\text { lit. There is no streaky bacon, which does not } \\
\text { finish one day }\end{array}$ \\
\hline Savanyú a szőlő & lit. Grapes are sour \\
\hline Senkinek sem repül sült galamb a szájába & lit. A roast pigeon will not fly into one's mouth \\
\hline $\begin{array}{l}\text { Sok darab kenyeret kell megenni, míg az ember } \\
\text { megismeri egymást }\end{array}$ & $\begin{array}{l}\text { lit. People must be consuming many bread slices } \\
\text { before they cognize each other }\end{array}$ \\
\hline Sok szakács elsózza a levest & lit. Many cooks oversalt the soup \\
\hline Széppel nem lehet káposztát főzni & lit. Beauty is not enough to cook cabbage \\
\hline Szépséggel nem lehet jóllakni & lit. Beauty is not enough to saturate \\
\hline Több nap, mint kolbász & lit. There are more days than sausages \\
\hline
\end{tabular}


There are more proverbs in this category deriving from either Latin or biblical sources A tiltott alma jobb izü /lit. Forbidden apple tastes better/; Borban az igazság /lit. In wine is truth - In vino veritas/; Fejétöl büzlik a hal /lit. The fish rots from the head down/; Nem csak kenyérrel él az ember /lit. Man shall not live by bread alone/; Savanyú a szölö /lit. Grapes are sour/ and/or largely spread like Evés közben jön meg az étvágy /lit. Appetite comes while eating $/-99^{\text {th }}$ position in the European proverbs dictionary (Paczolay, 2002).

The adjectives indicating taste are applied to define life situations (Aki a keserüt nem kóstolta, nem tudja, mi az édes /lit. Who didn't taste the bitter doesn't know what is sweet/; Keserü a más kenyere /lit. Others' bread is bitter/; Savanyú a szölö /lit. Grapes are sour/). Thematic proverbs are also applied as evaluation of certain activities (A puding próbája az evés /lit. The proof of the pudding is in the eating/; Sok szakács elsózza a levest/lit. Many cooks oversalt the soup/) or just the passivity (Senkinek sem repül sült galamb a szájába /lit. A roast pigeon will not fly into one's mouth/).

\section{d. Hungarikum items}

There are some specific proverbs in this subgroup, which depict the Hungarian lifestyle and habits. To determine such proverbs, we borrowed from Hungarian legislation the term Hungarikum which is widely applied in official communication. Hungarikum is a collectible term, indicating a value worthy of distinction and highlighting within a unified system of qualification, classification, and registry and which represents the high performance of Hungarian people thanks to its typically Hungarian attribute, uniqueness, specialty and quality.

Felmelegítve csak a töltöttkáposztajó /lit. Only the stuffed cabbage is good if warmed up/. The stuffed cabbage is a characteristic dish in the Hungarian gastronomy. Generally, many dishes made with cabbage are tastier on the day after they have been prepared. In this proverb this culinary observation is transmitted into area of human relationships. As soon as the love cools the "warming it up" can bring a disillusion.

Lesz még szölö, lesz még lágy kenyér/lit. There will be grapes, will be soft bread/. We find this proverb included in the XIX century Magyar közmondások és közmondásszerü szólások dictionary (Hungarian proverbs and proverb-like sayings) (Margalits, 1897). A few years later we meet the same proverb in the famous operetta Csárdáskirálynö (The Csárdás Princess) by the Hungarian composer Imre Kálmán with libretto written by Leo Stein and Bela Jenbach. It premiered in Vienna on 17 November 1915. And the proverb appears as a text for one the most popular arias in this operetta.

Nem eröszak a disznótor /lit. Nobody is forced to attend the dinner given after pig slaughtering/. Pig slaughter is an activity performed to obtain pig meat (pork). It regularly happens as part of traditional and intensive pig farming. Among the Hungarian folk customs and community events this one used to move - and moves also today - the most people. It takes place in the autumn and early winter between November and February. In most places, those involved in the work drink a blessing - usually palinka - before the pig is slaughtered. The actual work begins early in the morning with stabbing the pig. The processing of the meat is followed by dinner when freshly roasted pork sausage (kolbász) and black pudding are served. Such an occasion is considered not only a good possibility to be hosted at an exceptional dinner, but also an attractive community event. 
Több nap, mint kolbász /lit. There are more days than sausages/. In this proverb the sausage - a characteristic part of the traditional Hungarian cuisine (which is mainly intended as a homemade smoked, long-stored sausage) - personifies wealth and material goods. The message recommends preserving resources for a longer period and not to waste them.

e. The theory of the common Central-European linguistic area

The concept of areal typology was formulated for the first time by N.S.Trubetzkoy in his studies devoted to the contacts amongst genetically distinguished families of languages. In 1923 he formulated the definition of "language union" incorporating both genetically related and genetically unrelated languages. Later, during the course of the twentieth century, the idea of the Central European language area was further elaborated and supported in works of E. Lewy and V. Skalička. V. Skalička introduced a so-called Danube language union. This union includes Central European and partly Balkan languages: Hungarian, Czech, Slovak and partly German and Serbo-Croatian languages, although being independent in terms of their historical development.

The Czech linguist H. Kurzová broadened the Central European language area and included in it Czech, German, Hungarian and Slovak as central, Polish and Slovenian as marginal languages (Kurzova, 1996). H. Kurzová and S.M. Newerkla do not consider the language area as a territory limited by borderline, the language area is open.

After S.M. Newerkla and H. Kurzová, the Russian scholar O. Raina, in her 2008 Doctoral thesis on the paremiology of the Goral dialect of Polish, claimed the Goral dialect to the German, Hungarian, Czech, Slovak and Slovenian languages belonged to the Central European language area. This was the first attempt to perform a paremiological study within the framework of the theory of the Central European language area. In this study we support this approach and contribute to it.

Recently the Hungarian researcher T. Tölgyesi also dedicated multiple studies to the idea of the common Central-European linguistic area. Tölgyesi surveys the linguistic similarities, common roots and transitions within German speaking, Czech, Slovak, and Hungarian territories. He concluded, that one of the richest groups of the so called Austrianisms - loans from the Austrian German language - are the gastronomy related words. Our intention is to expand this theory to the paremiological level and to have a look what the situation is regarding the proverbs of our actual thematic group.

Altogether we identified 13 proverbs common for this area. After having filtered all these proverbs in the Matti Kuusi International type system most of them proved to be common either globally, or for certain regions. Only three proverbs in the given thematic group were not found in the Kuusi type system. (The literal English translation is made on the text of Hungarian proverb).

\begin{tabular}{|c|c|c|c|c|c|}
\hline English & Hungarian & German & Czech & Slovak & Slovenian \\
\hline $\begin{array}{l}\text { Mush/Soup } \\
\text { is not eaten } \\
\text { as hot as it is } \\
\text { cooked }\end{array}$ & $\begin{array}{l}\text { Nem eszik } \\
\text { olyan forrón } \\
\text { a kását (mint } \\
\text { ahogy fózik) }\end{array}$ & $\begin{array}{l}\text { Nichts wird } \\
\text { so heiß ge- } \\
\text { gessen wie es } \\
\text { gekocht wird }\end{array}$ & $\begin{array}{l}\text { Nic se nejí } \\
\text { tak horké, jak } \\
\text { se to uvaří }\end{array}$ & $\begin{array}{l}\text { Polievka sa } \\
\text { neje taká } \\
\text { horúca, ako } \\
\text { sa navarí }\end{array}$ & $\begin{array}{l}\text { Nobena juha } \\
\text { se ne poje } \\
\text { tako vroča, } \\
\text { kot se skuha }\end{array}$ \\
\hline
\end{tabular}




\begin{tabular}{|l|l|l|l|l|l|}
\hline \multicolumn{1}{|c|}{ English } & \multicolumn{1}{c|}{ Hungarian } & \multicolumn{1}{c|}{ German } & \multicolumn{1}{c|}{ Czech } & \multicolumn{1}{c|}{ Slovak } & \multicolumn{1}{c|}{ Slovenian } \\
\hline $\begin{array}{l}\text { Cheap meat } \\
\text { yields weak } \\
\text { soup }\end{array}$ & $\begin{array}{l}\text { Olcsó húsnak } \\
\text { híg a leve }\end{array}$ & $\begin{array}{l}\text { Was nichts } \\
\text { kostet, ist } \\
\text { nichts wert. } \\
\text { Wer billig } \\
\text { kauft, kauft } \\
\text { teuer }\end{array}$ & $\begin{array}{l}\text { Co nic ne- } \\
\text { stojí, za nic } \\
\text { nestojí. La- } \\
\text { ciné, dvakrát } \\
\text { placené }\end{array}$ & $\begin{array}{l}\text { Čo je lacné, } \\
\text { nie je vzácne. } \\
\text { Skúpy dva } \\
\text { razy kúpi }\end{array}$ & $\begin{array}{l}\text { Co je lacné, } \\
\text { nie je vzácne }\end{array}$ \\
\hline $\begin{array}{l}\text { Hunger is } \\
\text { a big lord }\end{array}$ & $\begin{array}{l}\text { Az éhség } \\
\text { nagy úr }\end{array}$ & & & $\begin{array}{l}\text { Hlad je naj- } \\
\text { lepš́ pán }\end{array}$ & \\
\hline
\end{tabular}

Searching for the origin of the above proverbs, the earliest mention found is of the second proverb Olcsó húsnak híg a leve /lit. Cheap meat yields weak soup/. In the Big dictionary of Hungarian proverbs (Litovkina, 2010) it is illustrated by quotations from the XVIII ${ }^{\text {th }}$ century literature. In the proverbs' collections it is included at the end of XIX $^{\text {th }}$ century (Sirisaka, 1890; Margalits, 1897). However, the proverbial parallel for the first one on our list Nem eszik olyan forrón a kását (mint ahogy fözik) /lit. Mush/Soup is not eaten as hot as it is cooked - The devil is not so black as he is painted/ is already included in the 1890 dictionary.

We tested the above three proverbs on 14 Hungarian respondents of different ages and grown up in different regions of Hungary. $100 \%$ of them revealed to know the first proverb, $93 \%$ the second proverb and $50 \%$ the third one.

\section{Conclusions}

Our study is an attempt of the comparative study of one thematic group of Hungarian proverbs in the framework of the Central European language area in the sense of the ideas of H. Kurzova, S.M. Newerkla, O. Raina, T. Tölgyesi and others.

Using the approach of sociolinguistic paremiological experiment, we revealed the frequency of Hungarian proverbs analysed in our paper. Our data are the following: German, Czech, Slovak and Slovenian proverbial parallels to Hungarian paremias belong to the active funds and are used currently in these languages.

Our comparative survey has fixed one common segment (Food and hospitality) of the proverbial world picture of 5 languages (13 Hungarian, 8 German, 12 Czech, 12 Slovak and 8 Slovenian proverbs). Altogether we identified 13 proverbs common exactly for the Central European language area and revealed the core of 3 proverbs: Nem eszik olyan forrón a kását (mint ahogy fözik) (in all 5 languages), Olcsó húsnak híg a leve (in all 5 languages), Az éhség nagy úr (only in Hungarian and Slovak).

Our study can be expanded in the future by potential research of the proverbs of marginal languages of the Central European language area: Polish, Serbian and Ukrainian. 


\section{References}

Kotova M.Yu. (2000), The Russian-Slavonic dictionary of Proverbs with English equivalents (in Russian: Русско-славянский словарь пословиц с английскими соответствиями), SaintPetersburg.

Kotova M., Raina O. (2020), Phenomenon of antonymy at the paremiological level of language, [in:] 13th Interdisciplinary Colloquium on Proverbs, ACTAS ICP19 Proceedings, Tavira.

Kotova M., Zimonyi-Kalinyina I. (2020), Hungarian proverbs with the components concerning food and hospitality, [in:] 13th Interdisciplinary Colloquium on Proverbs, ACTAS ICP19 Proceedings Tavira.

Kurzová H. (1996), Mitteleuropa als Sprachareal. [in:] Germanistica Pragensia, 13, Praha.

Kysel’ová N. (2002), Areálové vzájomné vzt’ahy slovanských jazykov centrálnej zóny, Banská Bystrica.

Lewy E. (1942), Der Bau der europäischen Sprachen. [in:] Proceedings of the Royal Irish Academy, 48, Section C, No. 2), Dublin.

Litovkina T.A. (2010), Magyar közmondások nagyszótára (The big dictionary of Hungarian proverbs), Budapest.

Margalits E. (1897), Magyar közmondások és közmondásszerü szólások, Budapest.

Múcsková G. (ed.) (2012), Slovenská jazykovedná spoločnost’ pri Jazykovednom ústave Ludovita Štúra, Bratislava.

Newerkla S.M. (2000), Language affinity in Central Europe - Some thoughts on the interrelations of German, Czech, Slovak and Magyar, [in:] Opera slavica: Slavistické rozhledy, 1-16.

Newerkla S.M. (2002), Středoevropský jazykový areál a rakouská Monarchie. [in:] Setkání s češtinou: Sborník z konference Setkání s češtinou konané v Praze 6.-7. záŕí 2001, Praha.

Newerkla S.M. (2007), Kontaktareale in Mitteleuropa. [in:] Słowiańsko-niesłowiańskie kontakty językowe: Materiały z międzynarodowej konferencji naukowej zorganizowanej przez Wydział Filologii Wszechnicy Mazurskiej i Instytut Filologii Germańskiej Uniwersytetu Gdańskiego w dniach 27-28 czerwca 2005, Olecko.

Newerkla S.M. (2007), Postavenie češtiny pri sprostredkovaní germanizmov do slovenčiny (a poľštiny). [in:] Slovenská reč, 21-35.

Paczolay G.Y. (2002), European proverbs in 55 languages with equivalents in Arabic, Persian, Sanskrit, Chinese and Japanese, Hobart, Tasmania.

Raina O. (2018), Goral Dialect as a Part of the Central European Area (on the Material of Proverbs), [in:] Advances in Social Science, Education and Humanities Research, volume 176. Proceedings of the $2^{\text {nd }}$ International Conference on Management, Education and Social Science.

Sirisaka A. (1890), Magyar közmondások könyve, Pécs, http://mek.oszk.hu/09100/09112/html/ index.html [assess: 8.06.2019].

Skalička V. (1935), Zur mitteleuropäischen Phonologie. [in:] Časopis pro moderní filologii, 21, https://doi.org/10.2991/icmess-18.2018.1 [access: 10.09.2019].

Tölgyesi T., https://www.academia.edu/37369287/Német cseh_szlovák magyar nyelvi kontaktusok a közép-európai_konyhamüvészet tükrében [access: 27.09.2019]. 
Tölgyesi T. (2012), O areálové lingvistice a středoevropském jazykovém Areálu, [in:] VARIA XX. Zborník príspevkov z XX. kolokvia mladých jazykovedcov, Bratislava.

Trubetzkoy N.S. (1923), Vavilonskaya bashnya i smesheniye yazykov, [in:] Evrazijskij vremennik, 3, Berlin.

Zimonyi-Kalinyina I. (2019), Hungarian Proverbial Parallels of the Russian-English Paremiological Core, [in:] 12 ${ }^{\text {th }}$ Interdisciplinary Colloquium on Proverbs, ACTAS ICP18 Proceedings, Tavira.

https://en.wikipedia.org/wiki/The Witness_(1969_Hungarian_film) [access: 16.09.2019].

http://www.hungarikum.hu/en [access: 20.04.2020].

https://en.wikipedia.org/wiki/Pig_slaughter [access: 23.04.2020].

https://www.britannica.com/topic/disznotor [access: 23.04.2020].

https://www.mattikuusiproverbtypology.fi/ [access: 5.05.2020].

\section{Streszczenie \\ Grupa tematyczna żywienie, kulinaria, gościnność w węgierskim zasobie paremiologicznym}

Celem niniejszego artykułu jest dobór węgierskich przysłów grupy tematycznej gastronomii i gościnności zarówno w sensie dosłownym, jak i przenośnym. W charakterze źródła wykorzystano ostatnie i wcześniejsze wydania słowników paremii. Przysłowia wybierano zarówno według słów kluczowych, jak i innych ich komponentów. Znaleziono znaczną ilość przysłów odnoszących się do danej grupy tematycznej. Za pomocą analizy porównawczej i opisowej cały zebrany materiał został podzielony na cztery podgrupy. Specjalny filtr semantyczny był zastosowany do identyfikacji w przysłowiach składnika specyficznych węgierskich realiów, tak zwanych „hungarikumów”. Dobór węgierskich przysłów danej grupy tematycznej był także wykorzystany do rozpatrzenia teorii wspólnego Środkowoeuropejskiego Obszaru Językowego.

Slowa kluczowe: kuchnia, gastronomia, gościnność, węgierski, hungarikum, przysłowia

\section{Аннотация \\ Тематическая категория питание, кулинария и гостеприимство в венгерском паремиологическом фонде}

Целью этого исследования является отбор венгерских пословиц тематической группы гастрономии и гостеприимства как в прямом, так и в переносном смысле. В качесте источника исследования использовались последние и более ранние издания словарей пословиц. Пословицы отбирались как по ключевым словам, так и по иным их компонентам. Было найдено значительное количество пословиц, относящихся к данной тематической группе. Путём компаративного и дескриптивного анализа весь найденный материал был разделён на четыре подгруппы. Особый семантический фильтр был использован для опознания в пословицах компонента специфических венгерских реалий, так называемых «хунгарикумов». Подборка венгерских пословиц данной тематической группы была также использована для рассмотрения теории совместного Центрально-Европейской лингвистического ареала.

Ключевые слова: кулинария, гастрономия, гостеприимство, венгерский, хунгарикум, пословицы 